\title{
Contribution of ASEAN-6 SMEs to Economic Growth of ASEAN
}

\author{
Badar Alam Iqbal, Mohd Nayyer Rahman \\ Aligarh Muslim University, Aligarh (UP), India
}

\begin{abstract}
The ASEAN (Association of Southeast Asian Nations) Economic Community Blueprint was adopted under declaration on the 40th Anniversary of ASEAN and the 13th ASEAN Summit in Singapore, among other parameters; it focused on equitable economic development. SME's (small and medium enterprise's) development with several pre-determined objectives was an important point of consideration under it. Out of the objectives, it was clearly laid down under ASEAN Economic Community Blueprint clause C1; one objective aims at increasing the contribution of SMEs to the overall economic growth and development of ASEAN as a region. The study investigated to present an overview of the SMEs contribution by ASEAN-6 (Brunei Darussalam, Indonesia, Malaysia, Philippines, Singapore, and Thailand) to the overall economic growth of ASEAN. For the said purpose, the research note addresses the theoretical background and definitions related to SMEs. Secondary data are used along with the descriptive statistics. The study concludes that SMEs are substantially contributing to the ASEAN as an economic region.

Keywords: SME's (small and medium enterprise's) contribution, ASEAN (Association of Southeast Asian Nations), employment, SME definition, growth rate, value added
\end{abstract}

\section{Introduction}

ASEAN (Association of Southeast Asian Nations) is a conglomeration of 10 countries, namely: Brunei Darussalam, Cambodia, Indonesia, Lao PDR, Malaysia, Myanmar, Philippines, Singapore, Thailand, and Viet Nam. ASEAN was established on August 8, 1967 in Bangkok. Indonesia, Malaysia, Philippines, Singapore, and Thailand are the founding fathers of ASEAN. Later on, the conglomeration was joined by Brunei Darussalam, Viet Nam, Lao PDR, and Myanmar in 1984, 1995, 1997, and 1997, respectively. Among several aims and purposes of ASEAN, one of the important aims is to accelerate the economic growth in the region through joint endeavours of the member states in the spirit of equality and partnership. On 40th Anniversary of ASEAN, the Vision 2020 was revised to form ASEAN Community with an objective of creating an economic and political community. The ASEAN Economic Community Blueprint, adopted under declaration on the 40th Anniversary of ASEAN and the 13th ASEAN Summit in Singapore, among other parameters, focused on equitable economic development (ASEAN, 2013). Creation of ASEAN Economic Community represents opportunity to encourage investment in the region that must lead to economic growth (Green, 2008). SME's

Badar Alam Iqbal, Ph.D., full professor of international business, Department of Commerce, Aligarh Muslim University, Aligarh (UP), India; and visiting emeritus professor; International University of Business, Agriculture and Technology, Dhaka, Bangladesh.

Mohd Nayyer Rahman, UGC senior research fellow, Department of Commerce, Aligarh Muslim University, Aligarh (UP), India.

Correspondence concerning this article should be addressed to Badar Alam Iqbal, Department of Commerce, Aligarh Muslim University, Aligarh (UP), 202002 India. E-mail: ba.iqbal.cm@myamu.ac.in. 
(small and medium enterprise's) development with several pre-determined objectives is an important point of consideration. Out of the objectives, clearly laid down under ASEAN Economic Community Blueprint clause $\mathrm{C} 1$, one objective aims at increasing the contribution of SMEs to the overall economic growth and development of ASEAN as a region. The research note aims to present an overview of the SMEs contribution by ASEAN-6 (Brunei Darussalam, Indonesia, Malaysia, Philippines, Singapore, and Thailand) to the overall economic growth of ASEAN. ASEAN-6 is a club of two distinct groups: one characterized by countries having high income and the other characterized by middle and near-middle income. This has been concluded by Green (2008). The ambitious aspirations of ASEAN Economic Community in 2015 need to be studied under the words of skeptical researchers of ASEAN (Narine, 2008).

\section{Theoretical and Conceptual Framework}

\section{SMEs Definition in Brunei Darussalam}

According to Table 1, SMEs are generally defined as those enterprises having six to 100 employees and constitute around $48.5 \%$ of all business establishments in the country. Statistics show that $50 \%$ of businesses in Brunei are made up of micro enterprises, having one to five employees; $46 \%$ represent small enterprises having six to 50 employees; and $2.5 \%$ of medium enterprises having 51 to 100 employees. In the context of Brunei Darussalam, SMEs thus could be defined as those enterprises having one to 100 employees that contribute around $98.5 \%$ of the total business establishments by incorporating micro, small, and medium enterprises.

Table 1

SME Definition in Brunei Darussalam

\begin{tabular}{lll}
\hline By segment & Criteria 1 & Value \\
\hline Micro & By number of employees & 1 to 5 \\
Small & By number of employees & 6 to 50 \\
Medium & By number of employees & 51 to 100 \\
Large & By number of employees & Above 100 \\
\hline
\end{tabular}

Source: Retrieved from http://www.asean.org/images/archive/SME/sme\%20basic\%20information\%20-\%20brunei\%20darussala m.xls.

\section{SMEs Definition in Indonesia}

It is clear from Table 2 that two simultaneous conditions have been used in order to define SMEs in Indonesia. Business units that have assets worth more than 50 million Indonesian Rupiah (US\$ 4,760) and up to 10 billion Indonesian Rupiah (US\$ 952,333) are considered as SMEs. In addition to this, another condition must also be checked upon, i.e., sales/year (turnover per year). For a business unit to be qualified as SME in Indonesia, the second condition must also be met. Under it, the sales per year must be more than 300 million Indonesian Rupiah (US\$28,570) with an upper limit of 50 billion Indonesian Rupiah (US\$ 4,761,667).

Table 2

SME Definition in Indonesia

\begin{tabular}{llllll}
\hline Segment & Criteria 1 & Value & $\&$ & Criteria 2 & Value \\
\hline Micro & Asset & Maximum IDR 50 mil. (US\$ 4,760) & $\&$ & Sales/year & Max Rp. 300 mil. (US\$ 28,570) \\
Small & Asset & > IDR 50 mil. to IDR 500 mil. & $\&$ & Sales/year & > IDR 300 mil. to IDR 2.5 bil. \\
Medium & Asset & > IDR 500 mil. to IDR 10 bil. & $\&$ & Sales/year & > IDR 2.5 bil. to IDR 50 bil. \\
\hline
\end{tabular}

Source: Retrieved from http://www.asean.org/images/archive/SME/sme\%20basic\%20information\%20-\%20indonesia.xls. 


\section{SMEs Definition in Malaysia}

Table 3 defines SMEs with respect to Malaysia. It uses a mutually exclusive criterion, either on the basis of sales turnover or on the basis of full time employees. It is to be noted that no other country under ASEAN-6 has used the term "full time employees". According to this definition, SMEs are those business units that have sales turnover between Malaysian Ringgit 250,000 and Malaysian Ringgit 25 million.

Table 3

SME Definition in Malaysia

\begin{tabular}{|l|l|l|}
\hline By segment & $\begin{array}{l}\text { Manufacturing, manufacturing related services, \& } \\
\text { agro-based industries }\end{array}$ & Services, primary agriculture, and information \& ICT \\
\hline Micro & $\begin{array}{l}\text { Sales turnover of less than RM250,000 or full time } \\
\text { employees less than five }\end{array}$ & $\begin{array}{l}\text { Sales turnover of less than RM200,000 or full time } \\
\text { employees less than five }\end{array}$ \\
\hline Small & $\begin{array}{l}\text { Sales turnover between RM250,000 and less than RM10 } \\
\text { million or full time employees between five and 50 }\end{array}$ & $\begin{array}{l}\text { Sales turnover between RM200,000 and less than RM1 } \\
\text { million or full time employees between five and 19 }\end{array}$ \\
\hline Medium & $\begin{array}{l}\text { Sales turnover between RM10 million and RM25 million } \\
\text { or full time employees between 51 and 150 }\end{array}$ & $\begin{array}{l}\text { Sales turnover between RM1 million and RM5 million } \\
\text { or full time employees between 20 and 50 }\end{array}$ \\
\hline
\end{tabular}

Source: Retrieved from http://www.asean.org/images/archive/SME/sme\%20basic\%20information\%20-\%20malaysia.xls.

\section{SMEs Definition in Philippines}

In Philippines, business units are treated as SMEs with respect to total asset valuation, as shown in Table 4. Total asset valuation is used by World Bank at global level.

Table 4

SME Definition in Philippines

\begin{tabular}{ll}
\hline By segment & Total asset value \\
\hline Micro & P3,000,000 or less \\
Small & P3,000,001 to $15,000,000$ \\
Medium & P15,000,001 to $100,000,000$ \\
\hline
\end{tabular}

Source: Retrieved from http://www.asean.org/images/archive/SME/sme\%20basic\%20information\%20-\%20philippines.xls.

\section{SMEs Definition in Singapore}

Singapore uses the criteria of annual sales turnover to define SMEs. SMEs are business units having annual sales turnover between Singapore Dollar 1 million and Singapore dollar 100 million. Small enterprises are those that have annual sales turnover between Singapore dollar 1 million and Singapore dollar 10 million and large enterprises are those having annual sales turnover between Singapore dollar 10 million and Singapore dollar 100 million.

Table 5

SME Definition in Singapore

\begin{tabular}{lll}
\hline By segment & Criteria 1 & Value \\
\hline Micro & Annual sales turnover & Less than SGD 1 million \\
Small & Annual sales turnover & More than SGD 1 million, less than SGD 10 million \\
Medium & Annual sales turnover & More than SGD 10 million, less than SGD 100 million \\
\hline
\end{tabular}

Source: Retrieved from http://www.asean.org/images/archive/SME/sme\%20basic\%20information-\%20singapore.xls.

\section{SMEs Definition in Thailand}

No specific definition of SMEs is available about Thailand. 


\section{Limitations of the Study}

The study is secondary in nature and uses the data available on websites and academic databases. The researcher had access to limited academic databases. Time and cost constraint was also a limitation with respect to the present study. For the study, the researcher had to rely on the government data by ASEAN which were not available for recent years. Due to this reason, data for 2012 and 2013 were not incorporated due to unavailability.

\section{Review of Literature}

In recent years, a growing interest in the importance of SMEs for economic growth has been observed in the literature, largely because this sector is responsible for the majority of employment generation in developed as well as in developing countries (Ayyagari, Beck, \& Demirguc-Kunt, 2007). Previous studies related to SMEs in general and to their economic contribution in particular identify their key importance in every economy. All over the world, SMEs are being supported on the grounds that they make substantial contributions towards competitiveness, productivity, and aggregate economic growth (United Nations Industrial Development Organisation, 2006). SMEs contribute to economic growth in several manners. One such method is their increasing involvement in international trade for which SMEs internationalise their activities (Coviello \& McAuley, 1999; Ruzzier, Hisrich, \& Antoncic, 2006). It may be observed that SMEs contribute in economic growth through the process of innovation. Hussain (2009) has identified the contribution of SMEs to gross domestic product (GDP). The relationship between SME growth and economic development can also be developed due to its positive effects on economic development, as it has been derived from previous studies (Gault, 2010). It has been identified that SMEs are of overwhelming importance for developing counties, because they account for more than $90 \%$ of all firms outside the agriculture sector, for example, it was identified with respect to Asian region that SME sector consists of more than $90 \%$ of all firms outside agricultural sector (Wattanapruttipaisan, 2003). Thus, SMEs are considered as engine of economic growth and development especially in the developing countries. SME sector in developing countries is typically dominated by labour intensive and low technology firms that are likely to be related with necessity entrepreneurship (Poschke, 2013). With respect to ASEAN economies, studies have concluded that their development is integral to achieve long-run sustainable economic growth (ASEAN, 2011). The contribution of SMEs to GDP has been in previous years between $30 \%$ and $53 \%$ and towards exports between 19\% and 31\% (ASEAN, 2011). In early 2011, the Indonesian Ministry of Industry targeted exports worth $\$ 200$ billion, in which the SME was the most valuable sector. Indonesian economy has seriously committed itself towards development of SMEs as an important foundation (Irjayanti \& Azis, 2012). In a particular study, it was found that Indonesia's SMEs are surrounded by abundant resources and easy availability of human resources (Chaminade \& Vang, 2008). SME has emerged as a priority sector in Indonesia for making economic policy target (Tambunan, 2008). SMEs may be regarded as backbone of Indonesian economy, due to the fact that $99 \%$ businesses are represented by SMEs, which contributes greatly towards the revenues of the economy. SMEs represent more than 50\% of Indonesia's total GDP and employ $97 \%$ of the labour force. The data of Ministry of Cooperation and SME list 55,530,000 SMEs in Indonesia for the year 2011 (Chaminade \& Vang, 2008). SMEs growth was stimulated due to proactive government support in Malaysia from 1996 to 2008. The government had taken direct initiatives over the period from 1981 to 2003, when funds and strategies targeted the growth of industrial SMEs during Dr. Mahathir Premiership. The seeds 
are reaping the benefits till today by adding to the economic growth of the country as well as towards ASEAN as an economic region (Rasiah, Rosli-Bin-Mohamad, \& Sanjivee, 2011). Most of the economies are dominated by SMEs that make the largest contribution to the economy (Kruja, 2013). Collecting finance has always remained a big problem for the SMEs. According to Y. Shen, M. Shen, Xu, and Bai (2008), SMEs in China obtain only $12 \%$ of their capital from bank loans, while their peers obtain $21 \%$ in Malaysia and $24 \%$ in Indonesia.

\section{SMEs Contribution in Overall Economic Growth}

\section{Brunei Darussalam}

As a percentage of private enterprises, SMEs in the region have always remained above $98 \%$ of the total private enterprises. This shows the importance of the SMEs and that how much economic activities SMEs are generating in the region. In absolute terms, number of SMEs has declined after 2008. The reason may be closure of badly managed firms or due to lack of finance. It has been that financial performance of small firms depends not only on firm specific factors but also on market features and especially on a country's economic and political risk (Majocchi, Dalla Valle, \& D'Angelo, 2013). The highest absolute increase in the number of SMEs was in the period from 2005 to 2006, when SMEs increased from 7,610 to 8,683 (an increase of 1,073). In the same period, private firms had increased from 7,716 to 8,790 (an increase of 1,074). It shows that $99.9 \%$ increase was in SMEs, while only an increase of $0.1 \%$ was in large private enterprises. The highest absolute decrease was in the period from 2008 to 2009, when SMEs decreased by 355 firms (9,150 in 2008 to 8,795 in 2009). SMEs in Brunei Darussalam are approximately present in every type of industry, but the top three industries where SMEs are present in large numbers are construction, wholesale, and retail of motorcycles (wholesale and retail and repair of motor vehicles and motorcycles) and accommodation and food services.

Table 6

GDP by Sector (BND Million at Current Prices)

\begin{tabular}{llllllll}
\hline Sector & 2004 & 2005 & 2006 & 2007 & 2008 & 2009 & 2010 \\
\hline Primary & 150 & 150.2 & 128.7 & 127.3 & 129.7 & 141.9 & 128.2 \\
Industrial & $9,028.4$ & $11,352.4$ & $13,336.9$ & $13,161.7$ & $15,117.5$ & $10,210.6$ & $11,262.9$ \\
Services & $4,127.4$ & $4,361.5$ & $4,760.2$ & $5,169.4$ & $5,150.7$ & $5,258.9$ & $5,476.3$ \\
Total GDP & $13,305.8$ & $15,863.9$ & $18,225.8$ & $18,458.4$ & $20,397.9$ & $15,611.4$ & $16,867.4$ \\
\hline
\end{tabular}

Source: Retrieved from http://www.asean.org/images/archive/SME/sme\%20basic\%20information\%20-\%20brunei\%20darussalam.xls.

Table 6 shows the GDP generation by SME under primary, industrial, and services sector classification. With respect to primary sector, the highest GDP generation was in the year 2005 and then there was decrease in GDP generation. However, the economy has generated 141.9 BND million in 2009 to recover the previous year good figures. But again in the year 2010, GDP contribution by primary sector declined and reached 128.2 BND million. The industrial sector in Brunei is the highest contributor towards GDP. Table 6 clearly states the following facts. Only SMEs in industrial sector have shown GDP generation in five unit figures. The highest contribution of industrial sector SMEs towards GDP was in 2008, when industrial SMEs contributed 15,117.5 BND million towards the GDP. SMEs coming under services sector have also contributed substantially towards GDP. In 2010, SME contributed 5,476.3 BND million towards GDP under services sector. If compounded annual growth rate (CAGR) is calculated to compare the contribution towards the GDP by SMEs (classified with respect to primary, industrial, and services sector), it makes the concept crystal clear. The compounded annual growth rate on GDP contribution by primary sector SMEs is negative, i.e., $-2.58 \%$. Industrial SMEs 
contributed with an overall CAGR of 3.75\% towards GDP and SMEs involved in service sector contributed with a CAGR of $4.83 \%$ towards GDP. Thus, the SMEs in service sector have shown the highest CAGR in contribution towards GDP, while in absolute terms, it is industrial SMEs that contribute maximum towards GDP in Brunei Darussalam.

\section{Indonesia}

Indonesian SMEs also play an important role in the economy by contributing both towards quantitative and qualitative parameters. Indonesian SMEs contribute towards entrepreneurship, innovation, employment, economic development, and economic growth. GDP may act as a parameter of overall economic growth. Table 7 below represents all the necessary quantitative details with respect to Indonesian economic growth, GDP, and Indonesian SMEs. An analysis of Table 7 will bring following points of consideration. GDP growth rate in the economy was the highest in 2007. Since then, it has declined but shown recovery in 2010. SME growth rate was the highest in the year 2006 after which growth rate has declined. The decline in SME growth rate may be due to already existing large number of SMEs. The SMEs' contribution to GDP in value terms has been increasing since 2005 and was the highest in the year 2010 with contribution standing at 1,282,571.8 million IDR. The CAGR of GDP value contribution by SMEs comes out to be $5.54 \%$.

In term of percentage of SMEs' contribution to GDP (calculated as GDP value contributed by SMEs to total GDP), it was the highest in the year 2006 with 58.49\% contribution. The important point to be noted is that Indonesian SMEs have always contributed more than $50 \%$ to the overall GDP. This shows their substantial contribution towards economic growth. SMEs have also contributed to exports and in terms of value, it was the highest in the year 2008 with a figure of 178,008.3 million IDR. SMEs have contributed with CAGR of 9.71\% towards the exports of Indonesia. In terms of percentage contribution to exports, it was the highest in 2005 (20.28\%) and it is to be noted that its contribution has always remained more than $15 \%$. It was argued in the previous sections that SMEs employ large labour force in developing countries. It would be interesting to study contribution of SMEs towards employment in Indonesia. Table 7 presents that in 2010, the number of people employed in SMEs in Indonesia was 99,401,775. In percentage terms, SMEs contribution to employment was 97.3\% in 2009 which was maximum. However, the contribution of SMEs towards employment has never been less than about $96 \%$. This shows the employment generation strength of SMEs in Indonesia.

\section{Malaysia}

Malaysian economy has long been involved in formulation of policies to boost the SMEs. Table 8 below highlights the contribution of Malaysian SMEs towards overall economic growth of the ASEAN as a region. On one hand, the GDP growth rate of Malaysia has increased from 5.3\% in 2005 to $7.2 \%$ in 2010, though among these years, there was a low GDP growth rate, but eventually it recovered. On the other hand, the SME growth rate was the highest in 2007 with a figure of $10 \%$, but since then, it has declined to eventually recover at 8.4\%. The SMEs' contribution to GDP in absolute valuation terms was the highest in the year 2010 with CAGR of $6.49 \%$. SMEs' contribution to GDP in percentage terms shows that consistently SMEs in Malaysia have contributed about $30 \%$ towards GDP and the highest contribution was in the year 2010 with a percentage contribution of $31.9 \%$. The governmental figures for exports contribution (in value) are not available except for the year 2005 which stands at 116,346 million RM that is $19 \%$ contribution. With the available data of four years (2005 to 2008) with respect to SMEs' contribution to employment, the highest numbers of employees were in the year 2008 with $3,684,210$ workers. In the same year, i.e., 2008, the highest was the SMEs' 
contribution to employment in Malaysia with a figure of $58.9 \%$. It would be justified to say that SMEs in Malaysia employ more than $50 \%$ of labour force. Another important point to be noted is that $90 \%$ of SMEs are in the services sector. This shows the type of SMEs that are in great number in Malaysia.

\section{Philippines}

The latest data of Philippines economy (Table 9) show that 79.55\% of SMEs are in service sector, while $13.68 \%$ SMEs are in manufacturing sector. SME in other sectors excludes agro-based SMEs and stands at 6.09\%. Thus, overall SMEs in Philippines represent service sector and SMEs would be contributing to overall economic growth through service sector. The GDP real growth rate was the highest in the years 2007 and 2010 (7.3\% in both) and in the period of five years (2007 to 2011), it has shown both trends of increase and decrease, for example, the real GDP growth rate declined from 2007 to 2009, but it increased in 2010 and again declined in the year 2011.

Philippines has not provided the details of SME contribution to GDP but has provided other parameters to measure overall economic growth. SME contribution to exports in percentage is not available for all years except for the year 2009, when it was $25 \%$. With a single figure, it would not be justified to reach a valid conclusion, but still it gives an idea of the importance of the SMEs in Philippines economy. SMEs' contribution to employment in terms of headcounts shows maximum number of employees in the year 2011 with 3,872,406 head counts in SMEs. This means that in percentage terms in 2011, SMEs employed $61.02 \%$ of the total employed labour force. However, the highest rate of employment in percentage terms by SMEs was in the year 2007 with a contribution of $64.69 \%$.

\section{Singapore}

Singapore is one of the important countries within the ASEAN-6 group. According to Table 10, the real GDP growth rate of Singapore was the highest in 2010, i.e., $14.8 \%$, while in the immediate preceding year, it was negative. Singapore has reached such a position from 7.4\% GDP growth rate in 2005 to $14.8 \%$ GDP growth rate in 2010. The SMEs real value growth rate was the highest in the year 2009 with a figure of $14.4 \%$, but it had declined in 2010 and reached 6\%. In terms of real value addition by SMEs based on 2005 prices, it was the highest in the year 2010 with a figure of 139.2 billion SGD. The CAGR if calculated comes out to be $5.8 \%$.

SMEs in Singapore have always contributed more than $50 \%$ to the total enterprises value addition in the economy. This shows the increasingly important role of SMEs in Singapore economy. Value added contributed is calculated by SMEs contribution by value to total value added of enterprises based on current market prices. The highest percentage of SMEs contribution was in the year 2009 with $58 \%$ contribution towards Singapore economy. In terms of employment generation, SMEs in Singapore have consistently contributed every year, the highest contribution being in the year 2009 and 2010 with employment of around two million workers. The percentage contribution of Singapore SMEs towards employment remained $70 \%$ all years except 2005 when it was marginally more, i.e., $71 \%$.

\section{Thailand}

According to Table 11, Thailand's GDP growth rate in 2010 was $7.8 \%$, which shows the strong position of the economy in the ASEAN region. In immediate previous year, i.e., in 2009, it was negative which shows that Thailand's policy makers have taken strong decisions that have boosted the GDP growth rate. Interestingly, the SME growth rate in Thailand was more than GDP growth rate in the years 2006 and 2010 with figures of 5.3\% and $7.9 \%$, respectively. 
Table 7

Indonesian SMEs Relevant Data

\begin{tabular}{|c|c|c|c|c|c|c|c|c|}
\hline Data name & Formula & Unit & 2005 & 2006 & 2007 & 2008 & 2009 & 2010 \\
\hline GDP growth rate & $\{(X 2-X 1) / X 2\} \times 100$ & $\%$ & - & 0.011 & 0.060 & 0.057 & 0.043 & 0.053 \\
\hline SME growth rate & $\{(X 2-X 1) / X 2\} \times 100$ & $\%$ & - & 0.041 & 0.022 & 0.025 & 0.026 & 0.020 \\
\hline $\begin{array}{l}\text { SME contribution to } \\
\text { GDP (value) }\end{array}$ & GDP value contributed by SMEs & Million IDR & $979,501.3$ & $1,035,615.2$ & $1,100,670.8$ & $1,165,753.1$ & $1,214,725.3$ & $1,282,571.8$ \\
\hline $\begin{array}{l}\text { SME contribution to } \\
\text { GDP }(\%)\end{array}$ & $\begin{array}{l}\text { GDP value contributed by SMEs \% to } \\
\text { total GDP }\end{array}$ & $\%$ & 55.95 & 58.49 & 58.44 & 58.35 & 58.17 & 57.83 \\
\hline $\begin{array}{l}\text { SME contribution to } \\
\text { export (value) }\end{array}$ & Value of export contributed by SMEs & Million IDR & $110,338.1$ & $123,767.9$ & $140,363.8$ & $178,008.3$ & $162,254.6$ & $175,894.9$ \\
\hline $\begin{array}{l}\text { SME contribution to } \\
\text { export }(\%)\end{array}$ & $\begin{array}{l}\text { Value of export by SMEs as \% of total } \\
\text { export }\end{array}$ & $\%$ & 20.28 & 17.95 & 17.66 & 18.10 & 17.02 & 15.81 \\
\hline $\begin{array}{l}\text { SME contribution to } \\
\text { employment (value) }\end{array}$ & No. of employment in SMEs & No. of headcounts & $83,586,616$ & $87,909,598$ & $90,491,930$ & $94,024,278$ & $96,211,332$ & $99,401,775$ \\
\hline $\begin{array}{l}\text { SME contribution to } \\
\text { employment }(\%)\end{array}$ & $\begin{array}{l}\text { No. of employment in SMEs as \% of } \\
\text { total employment }\end{array}$ & $\%$ & 96.85 & 97.30 & 97.27 & 97.15 & 97.30 & 97.22 \\
\hline
\end{tabular}

Source: Retrieved from http://www.asean.org/images/archive/SME/sme\%20basic\%20information\%20-\%20indonesia.xls.

Table 8

Malaysian SMEs Relevant Data

\begin{tabular}{|c|c|c|c|c|c|c|c|c|}
\hline Data name & Formula & Unit & 2005 & 2006 & 2007 & 2008 & 2009 & 2010 \\
\hline GDP growth rate & & $\%$ & 5.3 & 5.8 & 6.5 & 4.8 & -1.6 & 7.2 \\
\hline SME growth rate & & $\%$ & 6.9 & 7.4 & 10.0 & 6.4 & 0.4 & 8.4 \\
\hline $\begin{array}{l}\text { SME contribution to } \\
\text { GDP (value) }\end{array}$ & GDP value contributed by SMEs & $\begin{array}{l}\text { Value in currency } \\
\text { (RM mil.) }\end{array}$ & 130,173 & 139,800 & 153,814 & 163,733 & 164,400 & 178,275 \\
\hline $\begin{array}{l}\text { SME contribution to } \\
\text { GDP }(\%)\end{array}$ & $\begin{array}{l}\text { GDP value contributed by SMEs } \% \text { to } \\
\text { total GDP }\end{array}$ & $\%$ & 29.0 & 29.4 & 30.4 & 30.9 & 31.5 & 31.9 \\
\hline $\begin{array}{l}\text { SME contribution to } \\
\text { export (value) }\end{array}$ & Value of export contributed by SMEs & $\begin{array}{l}\text { Value in currency } \\
\text { (RM mil.) }\end{array}$ & 116,346 & na & na & na & na & na \\
\hline $\begin{array}{l}\text { SME contribution to } \\
\text { export }(\%)\end{array}$ & $\begin{array}{l}\text { Value of export by SMEs as \% of total } \\
\text { export }\end{array}$ & $\%$ & 19 & na & na & na & na & na \\
\hline $\begin{array}{l}\text { SME contribution to } \\
\text { employment (value) }\end{array}$ & No. of employment in SMEs & No. of headcounts & $3,172,117$ & $3,257,309$ & $3,529,121$ & $3,684,210$ & na & na \\
\hline $\begin{array}{l}\text { SME contribution to } \\
\text { employment }(\%)\end{array}$ & $\begin{array}{l}\text { No. of employment in SMEs as \% of } \\
\text { total employment }\end{array}$ & $\%$ & 56.8 & 56.9 & 58.2 & 58.9 & na & na \\
\hline
\end{tabular}

Source: Retrieved from http://www.asean.org/images/archive/SME/sme\%20basic\%20information\%20-\%20malaysia.xls. 
Table 9

Philippines SMEs Relevant Data

\begin{tabular}{|c|c|c|c|c|c|c|c|}
\hline Data name & Formula & Unit & 2007 & 2008 & 2009 & 2010 & 2011 \\
\hline GDP real growth rate & & $\%$ & 7.3 & 3.8 & 1.1 & 7.3 & 3.7 \\
\hline $\begin{array}{l}\text { SME contribution to } \\
\text { export }(\%)\end{array}$ & $\begin{array}{l}\text { Value of export by SMEs as \% of } \\
\text { total export }\end{array}$ & $\%$ & na & na & $\begin{array}{l}25 \% \text { of the country's total } \\
\text { exports revenue }\end{array}$ & na & na \\
\hline $\begin{array}{l}\text { SME contribution to } \\
\text { employment (value) }\end{array}$ & No. of employment in SMEs & $\begin{array}{l}\text { No. of } \\
\text { headcounts }\end{array}$ & $3,355,742$ & $3,395,505$ & $3,595,641$ & $3,532,935$ & $3,872,406$ \\
\hline $\begin{array}{l}\text { SME contribution to } \\
\text { employment }(\%)\end{array}$ & $\begin{array}{l}\text { No. of employment in SMEs as \% of } \\
\text { total employment }\end{array}$ & $\%$ & 64.69 & 61.24 & 63.19 & 62.32 & 61.02 \\
\hline
\end{tabular}

Source: Retrieved from http://www.asean.org/images/archive/SME/sme\%20basic\%20information\%20-\%20philippines.xls.

Table 10

Singapore SMEs Relevant Data

\begin{tabular}{|c|c|c|c|c|c|c|c|c|}
\hline Data name & Formula & Unit & 2005 & 2006 & 2007 & 2008 & 2009 & 2010 \\
\hline Real GDP growth rate & & $\%$ & 7.4 & 8.8 & 8.9 & 1.7 & -1.0 & 14.8 \\
\hline $\begin{array}{l}\text { SMEs' real VA } \\
\text { growth rate }\end{array}$ & & $\%$ & 11.3 & 7.8 & 11.2 & -8.9 & 14.4 & 6.0 \\
\hline $\begin{array}{l}\text { SMEs' VA (real } \\
\text { terms) }\end{array}$ & $\begin{array}{l}\text { VA (based on } 2005 \text { prices) } \\
\text { contributed by SMEs }\end{array}$ & SGD & 105.0 bil. & 113.2 bil. & 125.9 bil. & 114.7 bil. & 131.2 bil. & 139.2 bil. \\
\hline $\begin{array}{l}\text { SMEs' contribution to } \\
\text { total enterprises' VA }\end{array}$ & $\begin{array}{l}\text { VA contributed by SMEs to total VA } \\
\text { of enterprises (based on current } \\
\text { market prices) }\end{array}$ & $\%$ & 54 & 54 & 56 & 50 & 58 & 54 \\
\hline SMEs' employment & No. of employment in SMEs & $\begin{array}{l}\text { No. of } \\
\text { headcounts }\end{array}$ & 1.5 mil. & 1.6 mil. & 1.8 mil. & 1.9 mil. & 2.0 mil. & 2.0 mil. \\
\hline $\begin{array}{l}\text { SMEs' contribution to } \\
\text { total enterprises' } \\
\text { employment' }\end{array}$ & $\begin{array}{l}\text { No. of employment to total } \\
\text { employment of enterprises }\end{array}$ & $\%$ & 71 & 70 & 70 & 70 & 70 & 70 \\
\hline
\end{tabular}

Source: Retrieved from http://www.asean.org/images/archive/SME/sme\%20basic\%20information-\%20singapore.xls. 
Table 11

Thailand SMEs Relevant Data

\begin{tabular}{|c|c|c|c|c|c|c|c|}
\hline Data name & Formula & Unit & 2006 & 2007 & 2008 & 2009 & 2010 \\
\hline GDP growth rate & & $\%$ & 5.1 & 4.9 & 2.5 & 2.2 & 7.8 \\
\hline SME growth rate & & $\%$ & 5.3 & 4.8 & 2.0 & 2.4 & 7.9 \\
\hline $\begin{array}{l}\text { SME contribution to } \\
\text { GDP (value) }\end{array}$ & GDP value contributed by SMEs & Value in currency & $3,050,565.1$ & $3,298,529.4$ & $3,457,685.3$ & $3,417,860.7$ & $3,746,967.0$ \\
\hline $\begin{array}{l}\text { SME contribution to } \\
\text { GDP }(\%)\end{array}$ & $\begin{array}{l}\text { GDP value contributed by SMEs } \% \text { to } \\
\text { total GDP }\end{array}$ & $\%$ & 38.9 & 38.7 & 38.1 & 37.8 & 37.1 \\
\hline $\begin{array}{l}\text { SME contribution to } \\
\text { export (value) }\end{array}$ & Value of export contributed by SMEs & Value in currency & $1,452,479.0$ & $1,579,971.6$ & $1,691,144.5$ & $1,589,199.8$ & $1,753,804.3$ \\
\hline $\begin{array}{l}\text { SME contribution to } \\
\text { export }(\%)\end{array}$ & $\begin{array}{l}\text { Value of export by SMEs as \% of } \\
\text { total export }\end{array}$ & $\%$ & 29.5 & 30.1 & 28.9 & 30.9 & 28.4 \\
\hline $\begin{array}{l}\text { SME contribution to } \\
\text { employment (value) }\end{array}$ & No. of employment in SMEs & No. of headcounts & $8,637,126.0$ & $8,900,567.0$ & na & $9,701,354.0$ & $10,507,507.0$ \\
\hline $\begin{array}{l}\text { SME contribution to } \\
\text { employment }(\%)\end{array}$ & $\begin{array}{l}\text { No. of employment in SMEs as \% of } \\
\text { total employment }\end{array}$ & $\%$ & 76.5 & 76.0 & na & 78.2 & 77.9 \\
\hline
\end{tabular}

Source: Retrieved from http://www.asean.org/images/archive/SME/SME\%20Basic\%20Information\%20\%20-\%20Thailand.xls. 
In value terms, SMEs' contribution to GDP was the highest in the year 2010 with a figure of 3,746,967 CY. The CAGR of SMEs' contribution by value comes out to be $5.27 \%$. In percentage terms, SMEs' contribution to GDP was the highest in the year 2006, when it was $38.9 \%$ and has fallen to $37.1 \%$ in the year 2010. SMEs' contribution towards exports is also imperative for economic growth in the economy. SMEs' contribution to exports in Thailand was the highest in the year 2010 when it was $1,753,804.3$ CY from the previous figure of $1,452,479 \mathrm{CY}$ in 2006 . The CAGR comes out to be $4.83 \%$ in case of contribution to exports. SMEs' contribution to export in percentage was $29.5 \%$ in 2006 and then increased to $30.1 \%$ in 2007 . After that it again declined to $28.9 \%$ in 2008 , with marginal increase in 2009 to $30.9 \%$ (when it was the highest) to eventually reach $28.4 \%$ in 2010 . In order to contribute towards overall economic growth, SMEs are also contributing in employment process in the Thailand economy. In 2010, SMEs were employing 10,507,507 employees which increased substantially from 8,637,126 in 2006. Percentage wise of the contribution to employment by SMEs was the highest in the year 2009 with rate of $78.2 \%$.

\section{Conclusions}

In the end, it would be justified to conclude that SMEs are an integral part of ASEAN in general and of ASEAN-6 in particular. With respect to contribution to economic growth, ASEAN-6 economies are contributing substantially towards employment, exports, and GDP. Thus, SMEs of ASEAN-6 are contributing to the overall economic growth of ASEAN as a region. In addition to this, SMEs in ASEAN represent more than $90 \%$ of the total businesses. In order to facilitate the growth of ASEAN, developments of SMEs are very important. Thus, the future policy must necessarily address the impact on the contribution of SMEs towards economic growth of the region.

\section{References}

Association of Southeast Asian Nations Data and Statistics. SME basic information [Data file]. Retrieved from $\mathrm{http} / /$ www.asean.org/images/archive/SME/sme\%20basic\%20information\%20-\%20brunei\%20darussalam.xls

Association of Southeast Asian Nations Data and Statistics. SME basic information [Data file]. Retrieved from $\mathrm{http} / /$ www.asean.org/images/archive/SME/sme\%20basic\%20information\%20-\%20indonesia.xls

Association of Southeast Asian Nations Data and Statistics. SME basic information [Data file]. Retrieved from http://www.asean.org/images/archive/SME/sme\%20basic\%20information\%20-\%20malaysia.xls

Association of Southeast Asian Nations Data and Statistics. SME basic information [Data file]. Retrieved from http://www.asean.org/images/archive/SME/sme\%20basic\%20information\%20-\%20philippines.xls

Association of Southeast Asian Nations Data and Statistics. SME basic information [Data file]. Retrieved from http://www.asean.org/images/archive/SME/sme\%20basic\%20information-\%20singapore.xls

Association of Southeast Asian Nations Data and Statistics. SME basic information [Data file]. Retrieved fromhttp://www.asean.org/images/archive/SME/SME\%20Basic\%20Information\%20\%20-\%20Thailand.xls

Association of Southeast Asian Nations. (2011). ASEAN economic community factbook. Retrieved from http://www.thaifta.com/thaifta/portals/0/asean_aecfactbook.pdf

Association of Southeast Asian Nations. (2013). ASEAN economic community blueprint. Retrieved from http://www.asean.org/archive/5187-10.pdf

Ayyagari, M., Beck, T., \& Demirguc-Kunt, A. (2007). Small and medium enterprises across the globe. Small Business Economics, 29, 415-434.

Chaminade, C., \& Vang, J. (2008). Upgrading in Asian cluster: Rethinking the importance of interactive learning. Science, Technology and Society, 13(1), 61-94.

Coviello, N., \& McAuley, A. (1999). Internationalisation and the smaller firm: A review of contemporary empirical research. Management International Review, 39, 223-256.

Gault, F. (2010). Innovation strategies for a global economy. Ottawa, ON: International Development Research Council. 
Green, J. D. (2008). The role of ASEAN economic community as a commitment to policy certainty. ASEAN Economic Bulletin, 25(2), 209-227.

Hussain, A. (2009). Small business in Pakistan: Characteristics, problems and sources of finance. Retrieved from sbaer.uca.edu/research/icsb/2009/paper141.pdf

Irjayanti, M., \& Azis, A. M. (2012). Barrier factors and potential solutions for Indonesian SMEs. Procedia Economics and Finance, 4, 3-12.

Kruja, A. D. (2013). The contribution of SMEs to the economic growth (case of Albania). Euro Economica, 32(1), 55-67.

Majocchi, A., Dalla Valle, L., \& D’Angelo, A. (2013). Internationalisation, cultural distance and country characteristics: A Bayesian analysis of SMEs financial performance. Journal of Business Economics and Management, 16(2), 307-324.

Narine, S. (2008). Forty years of ASEAN: A historical review. The Pacific Review, 21(4), 411-429.

Poschke, M. (2013). Entrepreneurs out of necessity: A snapshot. Applied Economics Letters, 20, 658-663.

Rasiah, R., Rosli-Bin-Mohamad, M., \& Sanjivee, P. (2011). Production linkages, technological intensities and economic performance: Small and medium enterprises in Malaysian manufacturing. Asian Journal of Technology Innovation, 19(2), 279-296.

Ruzzier, M., Hisrich, R. D., \& Antoncic, B. (2006). SME internationalization research: Past, present and future. Journal of Small Bus Enterprise Development, 13(4), 476-497.

Shen, Y., Shen, M., Xu, Z., \& Bai, Y. (2008). Bank size and small- and medium-sized enterprise (SME) lending: Evidence from China. Journal of World Development, 37(4), 800-811.

Tambunan, T. T. H. (2008). Development of small and medium enterprises in ASEAN countries. New Delhi: Readworthy Publications Ltd.

United Nations Industrial Development Organisation. (2006). Productivity enhancement and equitable development: Challenges for SME development. Retrieved from http://www.unido.org/fileadmin/import/59567_06COMPID_0591423_Ebook.pdf

Wattanapruttipaisan, T. (2003). Four proposals for improved financing of SME development in ASEAN. Asian Development Review, 20(2), 66-104. 